\title{
BISHOP MOTIEJUS VALANČIUS, CATHOLIC UNIVERSALISM AND NATIONALISM
}

\author{
VYTAUTAS MERKYS
}

\begin{abstract}
The biography of Valančius has been investigated quite extensively by a number of writers (Antanas Alekna, Kazimierz Gieczys, Vaclovas Biržiška, Juozapas Stakauskas, et al.). In 1999 the monograph Motiejus Valančius. Tarp katalikiškojo universalizmo ir tautiškumo was published by the author of this paper, too. In those works ample use was made of previously published and archival materials, therefore the present paper aims at presenting a kind of biographical essay only rarely touching upon concrete events in the life and activity of the Bishop. The Catholic Church, the historical Lithuanian nobility with its prestigious Polish language, the Russian administration (and the Orthodox Church) as a rival of that former Lithuanian political nation, and lastly, the Lithuanian people - these were the four principal factors, which shaped the pastoral and cultural activities of Valancius. In his dealings with the Russian administration he had to uphold the legality of the Church policy and at the same time not to reconcile with the persecution of the Catholic Church and the enforcement of the Orthodox faith. The Bishop was always concerned with promoting a harmonious relationship between universal Catholic values and the cultural values of the historic Lithuanian nation and the Lithuanian people. A distinctive feature of his activity was his attention to the Lithuanian peasantry, treated by him as a potential mainstay of the Catholic Church and as a constituent part of a modern democratic Lithuanian nation and society, without radically conflicting with the local estate society. This societal education of the Lithuanian peasantry was implemented through the temperance movement led by Valancius, through the establishment of schools, the expansion of the social function of the Lithuanian language, the preparation, publication and dissemination of historical, religious and didactic and original fiction writings. Having exhausted all legal possibilities, the Bishop engaged in clandestine widespread anti-governmental Catholic and national activities.
\end{abstract}

The diocesan Bishop Motiejus Valančius of Žemaitija (or Telšiai) (1801-1875) was one of the most prominent leaders of the first stage of the Lithuanian national movement. He also won fame as 
the leader of the temperance movement both in his own and in the neighbouring dioceses.

In this paper we are interested not so much in evaluating Valančius as a famous representative of the Catholic Church, an ardent advocate of temperance, a writer and a founder of schools, as in determining the relationship between his Catholic values and Catholic universalism on the one hand and national values and élite and folk culture on the other.

Up to now the biography of Valančius has been investigated in the context of the history of the Church and literature. ${ }^{1}$ A theme similar to that of this paper was directly dealt with only in the discussion between Juozapas Stakauskas and Vaclovas Biržiška. In some of his publications Stakauskas argued that Valančius 'managed to combine the mediaeval ideal of Catholic asceticism with the ancient humanism of Hellas in the contemporary life of Lithuania'. In Stakauskas' words, 'in the most difficult times of repression this realistic practician applied all his energy to consciously serve the national ideal of his people'. ${ }^{2}$

Biržiška particularly criticized Stakauskas for presenting Valančius as a Lithuanian patriot. A serious deviation from patriotism, according to Biržiška, was the fact that despite his attachment to his native tongue, Valančius, nevertheless, recognized Polish as a medium of contemporary social communication and used Lithuanian only in his religious writings, pastoral letters and works of fiction meant for the common people. ${ }^{3}$

In his reaction to the criticism, Stakauskas explained that it was not his intention to write an extended biography of the Bishop; he only wanted to shed more light on his Lithuanianness. He also added that at that time the dominance of Polish was inevitable in theological literature and personal correspondence among intellectuals. ${ }^{4}$ In actual fact, both Biržiška and Stakauskas were right in their

${ }^{1}$ A. Alekna, Žemaičiu vyskupas Motiejus Valančius (Klaipėda, 1923), 2nd ed. Chicago, 1975; K. Gieczys, Bratctwa trzeźwości $w$ diecezji żmudzkiej $w$ latach 1858-1864. Dysertacja doktorska. Studja Teologiczne, vol. 4 (Vilnius, 1935); P. Puzaras, Vyskupo Motiejaus Valančiaus pastoracine veikla (Vilnius, 1992).

2 J. Stakauskas, 'Valančiaus laikų lietuviškas darbas', Tiesos kelias, no. 11, 1938, p. 748.

3 V. Biržiška, 'Iš vysk. Valančiaus veiklos', Mūsu senovè, Kaunas, t. 2, no. 3(8), pp. 355-371.

${ }^{4}$ J. Stakauskas, 'Valančiaus lietuvybès klausimas', Židinys, t. 39, no. 1, 1939, pp. 43-66. 
own ways, since they merely accentuated different aspects of the Bishop's activities. Their discussion was caused by their disregard for the absence of synthesis and causality of Valančius' actions.

The social and national situation in Lithuania was characterized by a specific interrelationship and seriously affected the Bishop's religious and social activity. The fate of the former Lithuanian political nobility, the consolidation of the modern democratic Lithuanian and Polish nations and the Valančius' participation in this process are the issues of this essay. ${ }^{5}$

The present paper is based not only on available scholarship, but also on archival materials, the greater part of which has not been used until the present time. They comprise Valančius' works, notes, letters, his own archive and those of the schools (both secular and religious) at which he studied, of the chanceries of the Žemaitian episcopal chapter and consistories, of the local and central offices of the Russian authorities, which controlled the activities of the Bishop and of the Catholic Church in general. These archives are in Vilnius, St Petersburg and other places. ${ }^{6}$

Valančius' social origin, his membership of the clerical estate and the entire socio-economic structure as well as Western European culture (in particular of the Catholic countries) conditioned the Bishop's activity. The influence of the latter factor is visible in his notes on the books he read, his commentaries on and quotations from foreign periodicals and other publications.

Valančius was born and bred in a north-eastern Lithuanian peasant family, which belonged to the Plateliai estate of the French count Marie-Gabriel Floretin Auguste Choiseul Gouffier in the county of Telšiai. His humble origin separated him like hundreds of thousands of young people of his social class from the entire gentry society from the very beginning, despite the fact that that society the clergy, the gentry and partly the townsmen - depended materially on the peasantry, which was not even recognized as a constituent part of contemporary society. The official extreme social conservatism and the laws of serfdom were serious obstacles preventing Valančius from leaving the village community, escaping

${ }^{5}$ A comprehensive biography of Valančius, see V. Merkys, Tarp katalikiškojo universalizmo ir tautiškumo (Vilnius, 1999).

${ }^{6}$ In greater detail about that, see Merkys, Tarp katalikiškojo universalizmo, pp. 24-30. 
bondage and acquiring the intellectual and social chances, equal to those of the élite estates of the clergy and gentry.

On the other hand, the beginnings of Valančius' acquisition of the universal and national values and preparation for their accumulation and generation lay in both gentry and peasant milieus. The attachment of the gentry to their estate and political traditions was conscious, and that is attested by their participation in the uprisings against Russian imperial rule. The peasants, leading a life independent of 'official society', saw their highest values in religion, ensuring moral perfection and the reward of the afterlife, and in their own folk culture - language, customs and folklore. In other words, while still in his native home Valančius acquired concepts of universal religious values and the Lithuanian culture of his parents. Whether the manifestations of universalism and nationalism would co-exist or whether universalism and official culture would subdue and ultimately destroy Valančius' initial national sentiment depended on his own life and the viewpoint he developed.

With the help of his parents and relatives, and in particular supported by his uncle, a priest, Valančius strove towards the gentry estate, securing the prospect of full membership of society. In order to be able to study he had to procure a false birth certificate. In his authentic certificate, a copy of which found its way into the archive of the consistory of the Žemaitian diocese, he is referred to as a son of the peasants by the name of Valančius (in the Latin original, 'Wałącius'), ${ }^{7}$ while in the corrected entry of the certificate book of the local church he is a son of parents called 'Wołonczewski'. ${ }^{8}$ That was a typical method practiced by those who did not belong to the noble estate (and had no serfs); proving one's titled origin by forged documents became popular when the Russian authorities started to check the roots of the nobility.

The 'improved' birth certificate was sufficient for the six-year school, run by the Dominicans in Kalvarija, where Valančius acquired his secondary education. That kind of certificate would not have been adequate to prove one's noble origin further. Luckily, it

${ }^{7}$ The filial church of Kalnalis, in which Valančius was baptized, was obliged to send a copy of the certificate to the consistory of the diocese; LVIA, f. 669, ap. 1, b, 104, 1. 783 .

${ }^{8}$ The certificate book of the church of Kalnalis, containing definitely later corrections of the certificate of Valančius, is currently kept in the Museum of Kretinga (western Lithuania). 
did not prevent Valančius from entering the clergy estate via relevant seminaries and ordination. In order to become a clergyman, a certificate of good birth was not crucial, the deciding factor was the attitude of the landowner, who could object to his peasant's studies.

Studies at the Seminary of Žemaitija, at the Principal Seminary of Vilnius and at the University of Vilnius assured Valančius not only ordination but higher education as well. ${ }^{9}$ Teaching theology in the secondary schools of Mozyr (Minsk gubernia) and Kražiai (Raseiniai county, Vilnius gubernia), and in the Roman Catholic spiritual academies of Vilnius and St Petersburg (here he became a doctor of divinity) led him to an important ecclesiastical appointment. In 1845 he was appointed rector of the Seminary of the Žemaitian Diocese (in Telšiai).

It is understandable that ordination and the acquisition of the theological degrees and titles was preceded by a good grounding in Catholic universalism and readiness to spread it through the Catholic Church. Its medium of communication was the Latin language, and the Bishop acquired perfect command of it and used it in his academic and administrative work. His pastoral activity required the knowledge of the 'local' language as well. It was Polish, the language of the historical political nation. The clerical estate had been integrated into the social and state system of the Republic of the Two Nations. The Republic had developed the political orientation of that estate and the conception of a 'civic' unity. These traditions were continued after the final partition of the Republic (1795) among its neighbours, when the grand Duchy was occupied by the Russian Empire. Polish remained the language of the clergy, nobility and gentry. The national policy of Russia and the Orthodox faith as a state religion led to discrimination against Catholics. The universal Catholic organization was treated by the Russian authorities as an oppositionist representative of a 'foreign religion', fostering the old state traditions of Poland and Lithuania. The locomotive power of all the uprisings against Russian rule in the Catholicinhabited regions was both the local gentry and the clergy.

In Valančius' times the spirit of the political past of the Two Nations permeated both the secondary schools and the university,

${ }^{9}$ Valančius' studies at the Principal Seminary of Vilnius and at the University of Vilnius and his way to the ordination are dealt with great detail in: I. Šenavičienè, Žemaičiu lituanistai Vilniaus vyriausiojoje seminarijoje. Motiejus Valančius (Vilnius, 1998), pp. 118-169. 
and not merely by the use of Polish. Although half a century later attempts were made to Russify both the secular and religious schools, in which Valančius worked, there are no indications that the Bishop would have approved of that policy of the Empire or would have resisted the old traditions of the elite estates, their historical political consciousness and the old concept of the Lithuanian political identity.

Simultaneously Valančius became involved in the process of the initial formation of the modern Lithuanian nation. That process was based not so much on the historical traditions, but on the rise of the peasantry as a major significant democratic force. It must be noted that at that time Lithuanian (currently called Lithuanian and Žemaitian) rather than Polish was used for internal pastoral purposes in the Diocese of Žemaitija. In this respect, this diocese differed from, say, the Diocese of Vilnius, in which Catholic hierarchs and the majority of local priests endeavoured to consolidate the positions of Polish as a second language after Latin even at the expense of the pastoral interests of the Lithuanians. Therefore, communication with the people in Lithuanian (Žemaitian) was common for Valančius, who used to call himself a priest of the people. However, his unequivocal treatment of the Lithuanian people as a non-estate society was most markedly expressed in his work Žemaičiu vyskupyste, written in the Žemaitian dialect. ${ }^{10}$ The author said he meant that history 'visu visiems žmonems' - for all the people (irrespective of estate).

He started writing the history while still in the Spiritual Academy of St Petersburg and finished it being rector of the Seminary of the Diocese of Žemaitija. Formerly it was believed that it was Simonas Daukantas, who induced Valančius to write the book in Lithuanian (Žemaitian). Daukantas, one of the first major figures of the Lithuanian national movement, worked at a department of the Senate, in which the Lithuanian Metrica, the archive of the chancery of the Grand Duchy of Lithuania, was kept. However, it would be naïve to think that Valančius surrendered himself to Daukantas' influence all of a sudden. It should be taken into consideration that it was the time when Johann Gottfried Herder's concept of the nations democratic by their social structure was spreading in Lithuania together with the idea of abolishing serfdom. The analysis of the atmosphere

${ }^{10}$ Motiejus Wołonczewskis, Żemajtiu wiskupiste, Wilniuj: Spaustuwieje Juozapa Zawadski, 1848 , d. 1, pp. 337 , d. 2, pp. 274 , a press run of 2,500 copies. The second (recent) edition: Motiejus Valančius, Raštai (Vilnius, 1972), pp. 475. 
in the contemporary Alma Mater shows that it was dominated not only by a conservative perception of the Republic of the Two Nations fostered by cosmopolitan-oriented noblemen, but also by attempts to continue the development of the modern Polish nation, which had been begun by the radical statesmen and cultural workers already before the destruction of the Republic. The alumnus Valančius must have maintained ties with an informal circle of Žemaitian students of the University, which was a kind of result of the influence of Herder's ideas, of the rebirth of the Polish nation and of the imminent social reforms. If the acquaintance struck by Valančius during his student days with his fellow student and one of the leaders of the Žemaitian circle, Simonas Stanevičius, meant national communication as well, then it could be stated that the idea of the Žemaičiu vyskupyste went back to the period of the University studies and then it developed during the years of his work in the secondary school of Kražiai, the Spiritual Catholic Academies of St Petersburg and Vilnius and the Seminary of the Diocese of Žemaitija. In conversation Valančius and Daukantas agreed about the necessity of enhancing the social prestige of Lithuanian, while Valančius also promised his friend he would write in Lithuanian. ${ }^{11}$

Valančius' becoming a bishop created new possibilities in his work of the development of Catholic universalism and nationalism.

The diocese taken over by Valančius had been enlarged some time previously when the Gubernia of Courland (formerly it belonged to the Diocese of Vilnius) was added to it with a rather large number of Latvian Catholics as well as four Lithuanian counties of the Vilnius gubernia. In 1857 there were 860,152 Catholics in the Diocese, and 51,327 belonged to the Gubernia of Courland. The expanded Diocese of Žemaitija made up possibly the most important area inhabited by Lithuanians at that time. The extension of its size alone created conditions for a more influential role of the Bishop's activities. The rise of his personality was also significant for the Church striving towards permanent renewal and social stability under changing political circumstances. Previously such high ecclesiastical posts were available only to the representatives of the nobility. Valančius' 'humble' origin was a kind of advantage, as in

${ }^{11}$ In his letter of 21 Jan. 1845 to a former member of the Lithuanian circle in St Petersburg Jonas Chrizostomas Gintila, Valančius wrote: 'I established contacts with Mr. Simonas [Daukantas], we are working on Žemaitian literature iunctis viribus, may be we shall get some result.' (Valančius, Raštai, t. 1, p. 501). 
his case the Russian authorities expected the Bishop to be less independent, less attached to the old political Lithuanian or Polish nations and consequently more loyal to the Empire. ${ }^{12}$ While appointing Valančius to the post of the bishop, the ecclesiastical administration sought greater activity and attention to the pastoral work, especially among the lower layers of the Catholic community, undergoing 'secularization' ${ }^{13}$. The commitment of the Church to its internal missionary activity - religious education, religious press, religious missions, etc., was encouraged by the Holy See, in particular in the face of revolutionary events in Western and Central Europe. That concern for the 'neglected' peripheral 'non-gentry' Catholic strata was related to the potentially growing social and economic role of the Lithuanian peasantry and the disintegration of serfdom.

Engaging in various pastoral tasks, the Bishop undertook administrative reforms in the diocese. He finally transferred the residence of the bishop and the chapter from a church estate in Alsedžiai (Telšiai county) to the 'historical' capital of the diocese, Varniai, in the same county, thus assigning greater significance to these institutions and stressing their universality for local Catholics. He considered the training of priests as the most important factor in the solution of the new tasks, and on becoming rector of the seminary he re-organized it, paying attention to theological and general education. He set up deanery libraries and introduced regular examinations of the priests, in particular while appointing them as rectors of parishes, and he inspected sermons. He also strictly controlled the administrative and moral discipline of the priests. In order to get personally acquainted with the parishes and the work of the priests

12 On 9 Sept. 1852 governor-general of Vilnius Il'a Bibikov wrote to his brother the internal minister Dmitrii Bibikov that 'for his present situation [Valančius] must be grateful only to the government'. LVIA, f. 378, PS, 1852 m., b. $131,1.13$.

${ }^{13}$ When Valančius, having no ecclesiastical titles, expressed his doubts as to his suitability for the high post, the Metropolitan of the Russian Catholics Archbishop of Mogilev Coadjutor Ignacy Hołowiński, whose task was to select the candidacies for new bishops, answered: 'Bishopric is not a reward for the emeriti or old men, neither is it a sinecure and bread buttered on both sides for those whose strength is already weak. In selecting people for this most important position attention is paid exceptionally to the person's religiousness, scholarship, life and capacity' (Hołowiński's letter to Valančius, LVIA, f. 1135, ap. 20, b. 336, 1. 38). 
he visited the churches of the diocese several times during his bishopric. Besides, he delivered the sermons for his believers in their native tongue, and he administered the sacrament of confirmation to as many as 752,402 Catholics. The Bishop's parish visits were always attended by great crowds, and the honour shown towards him caused the dissatisfaction and even threats of repression on the part of Russian authorities. ${ }^{14}$

Concerned with the rather neglected religious education of the people, the Bishop resorted to various new measures, ignored by his predecessors. First of all, he was worried about the state of the moral, religious, and, in general, cultural education of the people, thus revealing himself as a disseminator of the Enlightenment ideas of the University of Vilnius. He created a coherent system of people's education, in which a particular role was allotted to Catholic schools, teaching children the rudiments of literacy and faith in their native tongue. These schools were independent of state schools, in which all subjects except religion were taught in Russian - the state language. According to incomplete data, in 1861 in the Diocese of Žemaitija (with the exception of Courland) there were 147 schools dependent on the Bishop with 6,280 pupils, ${ }^{15}$ greatly exceeding the number of pupils at state primary schools. Additionally, there were many semi-clandestine small schools. Therefore, both contemporaries and historians state that Valančius made Lithuanians literate, since in his times around a third of local Catholics could already read books.

The rise of literacy was accompanied by the necessity of the access to Lithuanian books, the publication of which became another permanent concern of the Bishop. He himself wrote books and recruited the priests of his diocese for that job. The content of the books had to meet the requirements of the Church undergoing

14 There is much evidence about solemn receptions of the Bishop in the parishes. Thus, in 1858 Valančius himself wrote about his trip to Skapiškis, the county of Zarasai (Novo-Aleksandriisk): 'People met me a couple of miles from the town. The gates of triumph, flags, fluttering by the roadside... (Maciej Wołonczewski, Wiadomości o czynnościach pasterskich biskupa..., Lietuviu literatūros ir tautosakos instituto bibliotekos rankraštynas (Manuscript Division of the Institute of Lithuanian Literature and Folklore), Vilnius, f. 1, b. 4388, pp. 78-79).

15 The list of schools, sent by the Consistory secretary of the Diocese of Žemaitija to the Roman Catholic Spiritual College of St Petersburg on 14 Dec. 1863, LVIA, f. 669, ap. 3, b. 859, ff. 115-117. 
modernization, and their Lithuanian language had to be lively, correct and understandable for the representatives of all dialects. He himself (sometimes in co-authorship) issued about a hundred publications, some of them in several editions. ${ }^{16}$. However, among them there was not a single Polish publication, since, in his opinion, their demand was fully satisfied by Polish books brought from other dioceses.

As a genuine alumnus of the rationalistic University of Vilnius, the Bishop was an insidious enemy of prejudice, sorcery and similar beliefs. In this respect he issued two pastoral letters for his parishes. ${ }^{17}$ In his letters he taught people to understand the harmony between man and nature, to take care of domestic and wild animals, birds and flora. He perceived the protection of nature not only as a protection of wealth but also as a moral perfection of the personality.

The temperance movement (1858-1864), organized by the Bishop, was a part of his system of religious and moral education for the people. As many as 84 per cent of the Catholics of the diocese were involved in the movement, which subsequently became a priority in the Bishop's activity. It was fostered by all possible means - in sermons, through the press, circulars to the priests, and pastoral letters to all believers. As it is known now, altogether 19 pastoral letters were issued by Valančius on temperance, and only three of them were in Polish. ${ }^{18}$ That was due to the fact that the temperance movement as well as all the Lithuanian publications were centred around the common people.

Neighbouring dioceses were responsive to the temperance movement as well. Thus, the non-drinkers made up nearly 50 per cent of the Catholics in the diocese of Vilnius. ${ }^{19}$ The diocese of Žemaitija, headed by Valančius, became a leader of the temperance movement in the Russian Empire. The success of the movement, its scope, integrity and responsiveness were conditioned by

${ }^{16}$ Lietuvos TSR bibliografija, serija A: Knygos lietuviu kalba, t. 1, (15471861) (Vilnius, 1969), pp. 427-436, no. 1207-1236; t. 2 (1862-1904), d. 2 (Vilnius, 1988), pp. 240-268, no. 3614-3707.

${ }^{17}$ Motiejus Valančius, Ganytojiški laiškai, comp. V. Merkys and B. Vanagienė (Vilnius, 2000), pp. 43-50, 175-178, no. 4-5, 34.

${ }^{18}$ Ibid., pp. 58-89, 94-100, 107-151, no. 8-13, 15-16, 18-28.

19 V. Merkys, 'Vyskupas Motiejus Valančius ir blaivybės sajūdis Vilniaus vyskupijoje 1858-1863 m.', Lietuviu kataliku mokslo akademijos metraštis, t. 18 (2001), p. 49. 
the coincidence of the general pastoral aims with the social and national objectives of the people.

Temperance was especially detrimental to the landowners, who had the right of the liquor trade and to the tenants of their inns. The gentry and the inn-keepers of the towns were unanimous opponents of that movement, since they used to profit from the peasants even by forbidding them to drink in 'strange' (i.e., other owners') inns and treat their guests to alcoholic beverages in their own homes, e.g., at wedding, baptism, parties, etc. The sociologist Vytautas Kavolis rightly noticed that the temperance movement offered Lithuanians "the first peaceful model of "mass mobilization" (religious in content and national in form, and within it an exclusive use of the Lithuanian language'. ${ }^{20}$ In his pastoral letter of 28 October 1861 the Bishop himself wrote: 'The fame of the Žemaitians and Lithuanians quickly spread throughout the world; our homeland, formerly forgotten, listening to the Holy Mother Church, again became famous and honoured by the peoples of mankind'. ${ }^{21}$ At that time Valančius possibly understood that the peasants, formally freed from serfdom (it was abolished by the tsar's decree on 19 February 1861), were starting on a specific social life, and it was only a question of time when the so-called 'people' would perceive what 'homeland' and 'nation' are. No wonder that subsequently the Russian administration accused the Bishop and his temperance movement of nurturing the Uprising of 1863, and shortly afterwards the movement was strictly forbidden altogether.

Because of his concern for the poorer layers of the population, contemporaries and even the Russian authorities called Valančius the 'people's' bishop, while he himself used to say that he was a priest of the people. These characteristics of the Bishop can be accounted for not so much by his origin, but by his attention to the peasants, which he considered an important support of the Church and a constituent part of society. The humanistic treatment of moral, religious and ethic norms, the defence of the peasantry against the social and economic coercion of the landowners, the involvement of the Church in the regulation of the family relations between the peasants and the gentry, ${ }^{22}$ and the defence of the peasants against

${ }^{20}$ V. Kavolis, Žmogaus genezé (Vilnius, 1994), p. 446.

${ }^{21}$ Valančius, Ganytojiški laiškai, pp. 117, 119.

22 D. Marcinkevičiené, Vedusiu ju visuomenè: santuoka ir skyrybos Lietuvoje XIX amžiuje - XX a. pradžioje (Vilnius, 1999), pp. 41-45. 
the humiliation as feudal subjects without any rights were in great contrast with the former functions of the bishops, perceiving the social harmony between the gentry and the peasantry on the basis of the inviolability of conservative bondage relations. In times of crisis, for instance, during the Napoleonic invasion of Russia in 1812, a previous bishop of Žemaitija had issued a circular to the clergy to the effect that it was the peasants' duty to submit to the authority of their lords. ${ }^{23}$ Before Valančius possibly the only way to alleviate the social hardships was through parish poor houses. ${ }^{24}$

The idea that the norms of morality are universal and do not depend on an individual's social status, and Valančius' endeavours to put these norms into practice clashed with the privileges of the nobility and deepened the general crisis of serfdom.

The Bishop's orientation towards the peasants was also promoted by the policy of the authorities to undermine and eliminate ultimately not only the political, but also the social and cultural hegemony of the local gentry and Catholic clergy. The peasantry, having then been under the aegis of these classes, was becoming, after the abolition of serfdom, a firm pillar of the country's national identity and Catholicity.

The Bishop's turn from the old historical political nationalism towards the modern non-estate-bound Lithuanian nationalism could have begun during his studies in Vilnius, and in the course of time his orientation towards the peasantry was growing permanently. That process lasted until his death. Giving the Catholic peasantry prominence also meant the development of the Lithuanian national and cultural potential. It is noteworthy that among contemporary Lithuanian ideologues of the national movement, such as Daukantas, Valančius distinguished himself vividly by his pragmatism, vigour and social influence. The former were more prominent in the creation of national ideas, but their spread was relatively limited to the intellectuals, while the Bishop, although not revealing his national vision philosophically, accomplished much more by fostering the democratic nation practically and gaining the trust of the people as being 'one of their own'. The gentry landowners - the nucleus of

${ }^{23}$ A. Prašmantaitė, Žemaičiu vyskupas Juozapas Arnulfas Giedraitis (Vilnius, 2000), p. 279.

${ }^{24}$ R. Praspaliauskienè, Nereikalingi ir pavojingi: XVIII a. pabaigos $-X I X$ a. pirmosios pusès elgetos, valkatos ir plèšikai Lietuvoje (Vilnius, 2000), p. 41. 
the historical political Lithuanian nation - treated the Bishop with distrust and even hostility, seeing him not only a traditional Catholic hierarch, but also as a leader of the rising democratic movement.

The merit of Bishop Valančius consists in his defence of the 'non-prestigious' and 'uncivilized' Lithuanian language and culture; he did it using his hierarchic capacity and Church organization and far-sightedly envisaging the social and national modernization. Meanwhile the Russian Empire, following the example of other European empires, sought to unify the state with respect to religion and language resorting to nationalistically chauvinistic and 'Asiatic' methods. In the face of the approaching abolition of serfdom and the inevitable turn of the peasantry into 'citizens', the recognition of Russian as the only state language checked the development of peripheral peoples and their languages, national education, press, etc. The parish schools under the guidance of the Bishop, practically using no Russian, presented an obstacle to the state monopoly of education and safeguarded the cultural and religious identity of the country.

It is generally acknowledged that the most significant factor in the formation of modern nations is their periodical publications and books. The activities of Valančius created a demand for Lithuanian books and increased their assortment. When the temperance campaign was in full swing, the Bishop attempted to found a secular Lithuanian newspaper Pakeleivingas (Fellow-traveller). His endeavours, however, did not materialize, as the censorship (both civilian and military) obstructed the production of any non-Russian 'peripheral' publication. ${ }^{25}$

The concern for one's native tongue, its prestige, national education and press was then characteristic to the leaders of all subjugated peoples, and Valančius was not an exception. Relatively peaceful coexistence of the national ideologues, traditional society and the dominating culture was also common. In Valančius' works and practical activity there was no clear demarcation, let alone contradistinction, between 'us' (Žemaitians and Lithuanians) and 'them' (representatives of the gentry). Evident only were attempts to attach greater significance to 'us' in society and the life of the Church. Thus, in Valančius' times the development of the modern

${ }^{25}$ In greater detail, see Z. Medišauskienè, Rusijos cenzūra Lietuvoje XIX a. viduryje (Kaunas, 1998), pp. 217-271 ff. 
Lithuanian nation proceeded along the path of a moderate evolution and without any radical manoeuvres. A smooth Lithuanian national awakening was disturbed by a 'third' force - the Russian government. The Uprising of 1863 was a formidable challenge of the estates the clergy and gentry of historical Lithuania and Poland to Russian rule; that challenge ended in a catastrophic agony of the old Lithuanian political nation.

Valančius' position during the Uprising of 1863 was defined by the futility of the insurrection, and the Church's policy of legality and intent to protect the clergy, ordinary Catholics and Catholicism in general against a wave of repression. On every occasion the Bishop conducted negotiations on freeing arrested priests with Gen. Mikhail Murav'ev (nicknamed the Hangman), the supreme chief of the Northwest Gubernias, appointed by the tsar. The Bishop's activities permanently bordered on legitimacy. Under pressure of the authorities he issued a pastoral letter of 6 September 1863, urging the people to discontinue the uprising and recognize the rule of the Russian emperor and his administration. ${ }^{26}$ Valančius' policy of legalism does not lead to the idea that he was an adversary of the uprising (though the insurgents required that he publicly endorsed their actions). After all, the insurgents were Catholics, the sheep of his flock. Besides, the Bishop never strove to come into conflict with the historical Lithuanian nation and its political vision. Catholicism itself was a component of the culture and spiritual life of that nation. What is more, the 'Žemaitian and Lithuanian' peasants, the Bishop's dearest flock, together with the gentry and clergy, made up about a half of the insurgents of the diocese. Valančius was a person of a realistic mindset, and he had to perceive quite definitely that the modern Lithuanian nation was still in the process of formation and was not yet ready for independent political actions.

Doubtless, the government was interested in involving the Bishop, as if he were an official of its own administration, in the political and military actions to pacify the country. Those endeavours were of no avail. Already in 1864-1865 Valančius circulated three confidential letters to the priests in Lithuanian, Polish and Latin (instead of the required Russian). He indicated that when any ills of life befall the country, the clergy must strictly adhere to the ecclesias-

${ }^{26}$ Valančius, Ganytojiški laiškai, pp. 167-170. 
tical discipline, be zealous pastoral workers, take care of the religious education of parishioners, and not indulge in political conformism for the sake of career and by every available means oppose the Orthodox faith, enforced by the Russian administration. ${ }^{27}$

In 1863 schools, established by Valančius, were closed, and in all other schools Russian was permitted as the only language of instruction. In 1864 and 1865 the Bishop submitted three projects on the re-establishment of Catholic Lithuanian parish schools: on the teaching of Catholic faith in state schools in Lithuanian and on the establishment of the first Lithuanian secondary school - a sixyear Junior Seminary (for 120 students) with Lithuanian as the language of instruction. ${ }^{28}$ Of all the projects only one was accepted and approved - on teaching Catholic faith in primary state schools in Lithuanian.

The Uprising of 1863 was the dividing line separating Valančius' activity into two periods. The Uprising changed radically the entire situation of the Catholic Church, the conditions and methods of the performance of the bishop's duties and relations with the Russian administration. The Bishop, his chapter and consistory as well as the seminary were forcibly transferred to Kaunas, where it was more convenient for the authorities to watch the moves of the Bishop and the activities of his ecclesiastical institutions. In Kaunas the Bishop became a real captive: he was forbidden to travel more than ten versts (a verst is $1.07 \mathrm{~km}$ ) beyond the city boundaries. When in 1868 he received a convocational bull from Pope Pius IX to attend a general Church Council, he applied to the governor of Kaunas for the tsar's permission to go to Rome. The governor derisively replied - did Valančius think that Rome lay within ten versts of Kaunas? The tsar did not give permission either. Episcopal visits to parish churches and corresponding religious services were banned. Therefore in 1865 Kaunas was flooded by crowds of believers from the Diocese of Žemaitija and from other dioceses. The main aim of these trips was to receive the sacrament of

27 The first two letters (in Lithuanian and Polish) are dated 13-14 Sept. 1864, the third (in Latin) of 6 Febr. 1865; they are published in: J. Stakauskas, 'Valančiaus laiku lietuviškasis darbas', Tiesos kelias, no. 7/8, 1938, pp. 511-512; I. Šenavičienè, 'Motiejaus Valančiaus laiškai Eligijui Mantvilai', Lituanistica, no. 1(24), 1997, pp. 99-102, the second (Latin) circular is furnished with an official French translation; LVIA, f. 378, BS, 1864 m., b. 1396, ff. 2-3.

28 The Russian originals of these projects are kept in LVIA, f. 378, BS, 1864 m., b. 1615 , ff. 5-8. 
confirmation from the hands of the Bishop. Every day between 120 and 2,000 people came to the city. The Russian authorities treated it as a political demonstration and resorted to strict police and even military measures. That movement, religious in its essence and provoked in the first place by the persecution of the Bishop and the Catholic Church, set 'us' against 'them' and 'unexpectedly turned into a favourable medium for the growth of Lithuanian national consciousness'. ${ }^{29}$

The threat of the Bishop's removal was also an incentive for the peasants to go to Kaunas, the more so that since 1863 nearly all Catholic dioceses in the Empire had remained without bishops. The harmful influence of the Bishop was authoritatively characterized by the governor of Kaunas in 1867: 'There is no doubt that a single word of Bishop Wołonczewski would put an end to the still continuing revolutionary strivings of the Catholic clergy. Controlling the diocese for a long time he [the Bishop] attained great authority. His word could radically change the political situation in the gubernia, ensure peace among the peasants, undoubtedly influenced by local priests, who have been democratized insistently and systematically by Bishop Wołonczewski'. ${ }^{30}$ Nevertheless, the government feared that by removing the Bishop it could aggravate the strained political situation in the country. Besides, there was no suitable candidate for the post, a Polish bishop would not have been a lesser evil, and there were considerations even to invite a bishop from abroad from the German countries.

Changes also took place in the nature of Valančius' communication with the gentry and the peasantry. After the Uprising the gentry estate lost its former dominating role in society in the aftermath of the repression, the abolition of serfdom and the reconstruction of the estate economy. Eventually the economic and social situation of the peasantry was changing for the better. The Russian government made a great effort to integrate those peasants into the Russian political nation and the Orthodox Church. In addition to Lithuanian Catholic schools, all Lithuanian publications in the Latin alphabet were banned in 1864-1865; instead the publishing of Lithua-

${ }^{29}$ I. Šenavičienè, 'Kataliku bažnyčios 1865 m. religinè kova ir jos reikšmė lietuvių tautiniam atgimimui', Lietuvos aukštuju mokyklu mokslo darbai. Istorija, t. 44,2000 , p. 33 .

${ }^{30}$ Governor of Kaunas Mikhail Obolenskii's letter of 16 Jan. 1867 to governor general of Vilnius Eduard Baranov, LVIA, f. 378, BS, 1865 m., b. 497, ff. 38-39. 
nian $\mathrm{ABC}$ books, calendars, even the most elementary Catholic religious books in the Cyrillic alphabet was introduced. These official publications were supposed to accelerate the Russification of the population and its conversion to Orthodoxy. Cyrillic Catholic books were arbitrarily adjusted to Orthodox dogmas.

Deprived of the chance to act only legally, Valančius engaged in an intensive forbidden Lithuanian cultural and pastoral work. He created a secret press and started publishing Lithuanian books in Prussia, thus continuing the production of traditional religious books. The Bishop himself wrote four didactic books, now treated as classical works of Lithuanian literature: Vajku kningiele (A Little Book for Children), Paugusiu cemoniu kningiele (A Little Book for Adults), Patangos Juze (Juze of Palanga) and Pasakoimas Antana tretinika (The Story of the Tertiary Antanas).

In addition, the Bishop also wrote eight militant religious booklets, the most significant of which was Wargai Bažniczes Kataliku Letuwoj ir Zemajcziusi (The Hardships of the Catholic Church in Lithuania and Žemaitija). The appearance of these booklets was provoked by the policy of the Russian Empire. Valančius used the press as a means of religious and political propaganda. At that time he was the only intellectual capable of doing that sort of job. He also defended his native tongue by categorically opposing the introduction of Russian in religious services. The opposition of the people, nurtured by those booklets, to religious discrimination 'was not difficult to transfer onto the national plane. Thus Valančius prepared and solidified morally the peasant nation for the rebirth movement and made it resistant to the imperial policy of coercion'. ${ }^{31}$

The first clandestine organization, engaged in publishing and dissemination of Lithuanian books, consisted mostly of young reliable priests and their several helpers along the Russo-Prussian border. It functioned between 1867 and 1870, until it was discovered by Russian gendarmes. During the interrogations the authorities learned that the Bishop was the principal leader of the organization. However, they could not find any material evidence, any of the Bishop's manuscripts, even with the help of Prussian authorities. The searches in his apartment were not successful, either.

31 V. Zaborskaite, 'Tarp modernejjančios visuomenès galimybių. Motiejaus Valančiaus charakteristikos ir studijų eskizas', Metai, no. 2, 2001, p. 101. 
The arrested members of the organization were imprisoned without any trial, convicted by the administration and exiled to the far-off regions of the northern or Siberian gubernias at the tsar's pleasure. However, they did not dare to arrest the Bishop. The governor of Kaunas, who was authorised to admonish him, merely heard from him the denial of his guilt and his resolute decision: 'Well, what then? Goodbye, you can hang me, exile me to Siberia; I'm already old and that's my only wish'. ${ }^{32}$

The historiographical dispute about whether Valančius was more concerned with the national issues or with those of the Church and the argument that he sacrificed the national interests for those of the Church are merely misunderstandings. They appeared due to a later conjunctural conception of the relationships between the historical and modern Lithuanian nations and the Church. In Valančius' times the modern Lithuanian nation was only in its embryonic form, and the Lithuanian spirit had yet to be awakened and fostered. Being a bishop, Valančius had a tremendous field of activity and incomparably better conditions than any other intellectuals writers, cultural workers, etc., who lived either at the expense of a landowner or made their living as ordinary clergymen or civil servants.

The farsightedness of the Bishop, his perception that principally Lithuanian peasants (and lower gentry) rather than the landowners determined the process of the national modernization of the country and became the main bulwark of the Church, proved to be correct in the course of time. The national awakening of the Lithuanian peasants and their attachment to their Bishop and the Church was an effective barrier against forcible Russification and instilment of Orthodoxy. The fact that throughout his life the Bishop did not write a single religious, didactic or any other book in the then prestigious Polish language attests to his Lithuanian orientation.

The specificity of Valančius' phenomenon is the harmony of Lithuanian nationalism and Catholicism and the perception of the historical prospect. The Bishop managed to combine Catholic universalism with nationalism. In his time the Catholic Church was an important source of the cultural values of Western Europe, which underwent local adaptation, merged with folk culture and became

${ }^{32}$ A copy of the governor of Kaunas Obolenskii's letter of 20 March 1871 to governor general of Vilnius Aleksandr Potapov, RGIA, op. 125, d. 3071, ff. $74-75$. 
a constituent part of the developing Lithuanian national culture. It must be acknowledged that at that time when the changing Lithuanian society was not yet ripe for wide secularization, the involvement of the Church in the development and fostering of Lithuanian nationalism were the Bishop's conspicuous merits.

\section{Author Details}

Vytautas Merkys is Professor of Lithuanian History; his research is mainly in the areas of Lithuanian culture and the national movement in the nineteenth century. He has published several monographs on outstanding figures of the Lithuanian national revival and on the landmarks of that period.

Address: Department of 19th-Century History, Lietuvos istorijos institutas, Kražių 5, LT-2001 Vilnius, Lithuania

Email: istorija@comliet.lt

\section{VYSKUPO MOTIEJAUS VALANČIAUS KATALIKIŠKASIS UNIVERSALIZMAS IR TAUTIŠKUMAS}

Santrauka

\section{VYTAUTAS MERKYS}

Jau nemažai turime M. Valančiaus biografijos tyrinėjimu (A. Aleknos, K. Gečio, M. Biržiškos, J. Stakausko). 1999 m. išèjo ir mūsų monografija Motiejus Valančius. Tarp katalikiškojo universalizmo ir tautiškumo. Kadangi šiuose leidiniuose panaudoti gausūs publikuoti ir archyviniai šaltiniai, todèl anglų kalba publikuojamas straipsnis - savotiška biografinè esé, kur kartais nurodomos konkrečios M. Valančiaus gyvenimo ir veiklos gairès.

Katalikų Bažnyčia, isrtorinè bajoriška lietuvių tauta su savo prestižine lenkų kalba, šios buvusios politinès tautos konkurentè rusų administracija (su Stačiatikių Bažnyčia) ir lietuvių liaudis - tai tie pagrindiniai keturi veiksniai, kurie lėmė M. Valančiaus ganytojiško darbo ir kultūrinès veiklos ypatybes. Bendraujant su rusų administracija, laikytasi Bažnyčios legalumo politikos, bet nesitaikstyta su katalikų tikejjimo persekiojimu ir stačiatikybės brukimu. M. Valančius visuomet rūpinosi universaliujų katalikiškų vertybių harmonija su istorinès lietuvių tautos ir lietuvių liaudies kultūros vertybėmis. Tačiau išskirtinis M. Valančiaus veiklos bruožas - tai atsigręžimas ị lietuvių valstiečius, siekiant be radikalaus supriešinimo su vietine luomine visuomene juos ugdyti kaip perspektyvią Bažnyčios atramą, kaip visuomenės ir svarbiausią moderniosios demokratinès lietuvių tautos dalị. Šis visuomeninis 
lietuvių valstiečių ugdymas reiškèsi M. Valančiaus vadovaujamu blaivybės sajūdžiu, mokyklų steigimu, liaudies švietimu, lietuvių kalbos visuomeninių funkcijų plètimu, istorinès, religinès moralinès literatūros, originalios beletristikos rašymu, rengimu, leidimu ir platinimu. Kai nebeliko legalių veiklos galimybių, M. Valančius pirmasis èmési gana plataus slapto antivyriausybinio katalikiško ir lietuviško darbo.

Received 12 September 2001 